\title{
Effects of strength training on blood lipoprotein concentrations in postmenopausal women
}

\author{
Efeitos do treinamento de força sobre as concentrações de lipoproteínas \\ sanguíneas em mulheres pós-menopausa
}

\author{
Cleiton Silva Correa ${ }^{1,2}$, Bruno Costa Teixeira ${ }^{1}$, Aline Bittencourt ${ }^{1}$, Álvaro Reischak-Oliveira $^{1}$
}

\begin{abstract}
Strength training is often identified as a contributing factor in prevention of diseases and as a non-pharmacological treatment for metabolic disorders and for control of body mass. Its protective effects and utility for management of disease are amplified in people at risk of diabetes mellitus and dyslipidemias, and cardiovascular diseases (CVD). Recently, the benefits of strength training have been used to reduce the risk of these diseases emerging in postmenopausal women, who are at greater risk of CVD than men of the same age. Notwithstanding, little is known about the effects of strength training on metabolism of blood lipoproteins. The objective of this review was to compare the results of articles that have investigated the effects on lipoprotein concentrations of strength training in postmenopausal women. Current articles dealing with the subject, with publication dates from 1979 to 2012 and large numbers of citations by well-known researchers were identified on the Pubmed, Scopus and EBSCO databases. It was concluded that strength training possibly has an action that affects lipoprotein metabolism and concentrations in postmenopausal women.
\end{abstract}

Keywords: menopause; basal metabolism; physical exercises; atherosclerosis.

\section{Resumo}

O treinamento de força tem sido frequentemente relacionado como contribuinte para a prevenção do aparecimento de doenças e como tratamento não farmacológico para distúrbios metabólicos e controle de massa corporal. Os efeitos protetores e de manejo de doenças se ampliam para sujeitos com riscos para diabetes mellitus e dislipidemias, e doenças cardiovasculares (DCV). Recentemente, os benefícios do treinamento de força têm sido usados para reduzir o risco do aparecimento dessas doenças em mulheres pós-menopausa, as quais apresentam um risco maior para desenvolver DCV quando comparadas aos homens de mesma idade. Entretanto, pouco se sabe sobre a efetividade do treinamento de força sobre metabolismo das lipoproteínas sanguíneas. O objetivo desta revisão foi comparar os resultados de artigos que abordaram os efeitos do treinamento de força em mulheres pós-menopausa e quais os resultados sobre as concentrações de lipoproteínas. Foram pesquisadas referências atuais sobre o tema a ser abordado, sendo que os artigos foram selecionados nas bases de dados Pubmed, Scopus e EBSCO, artigos atuais datados do período de 1979 a 2012, com grande número de citações de pesquisadores renomados no assunto. Em conclusão, o treinamento de força possivelmente tenha uma ação efetiva no metabolismo e na concentração de lipoproteínas em mulheres pós-menopausa.

Palavras-chave: menopausa; metabolismo basal; exercícios físicos; aterosclerose. 


\section{INTRODUCTION}

Aging of the global population is a recent phenomenon in the history of humanity. Currently, $10 \%$ of the population in the majority of developed countries are more than 50 years old and $95 \%$ of women reach menopause (i.e. last menstruation, confirmed 12 months after amenorrhea caused by failure of the ovaries). Physical aspects of general health and emotional wellbeing suffer decline during the transition to menopause. Climacteric symptoms affect 60 to $80 \%$ of women and are known to cause physical and emotional discomfort, which increase in line with the severity of symptoms. Physical exercise is often linked with prevention of these symptoms and with emergence of diseases, in addition to being used in non-pharmacological treatment for metabolic and cardiovascular disorders. ${ }^{1}$

The majority of investigations involving physical exercise have concentrated on studying the effects of aerobic and/or anaerobic exercise on lipid metabolism, primarily during the postprandial period. ${ }^{1,2}$ Some authors have observed that exercise has effects on blood parameters in populations at increased risk of developing cardiovascular diseases (CVD), such as women in the postmenopausal period. ${ }^{3,4}$

Cardiovascular diseases are responsible for more than $33 \%$ of deaths worldwide and for $23 \%$ of female mortality and are the number one cause of death among women over 60 years of age. ${ }^{5,6}$ It is believed that the increased vulnerability is related to reduced serum estrogen levels (i.e. endogenous estradiol), which plays a cardioprotective role by promoting an antiatherogenic lipid profile and by direct action on endothelium. Additionally, the incidence of obesity in this age group is greater among women than among men, because of higher rates of physical inactivity and fat-rich diets, ${ }^{7,8}$ further increasing their propensity to CVD.

Some authors have demonstrated and argued in favor of the beneficial effects of strength exercise (SE), which consists of exercises performed against an external resistance (weights, machines employing pulleys, bars or own body weight) and are primarily used to increase muscle strength. It has been observed, however, that strength training can also be used to reduce postprandial lipemia (PPL), through increased activity of lipoprotein lipase (LPL), a key enzyme in hydrolysis of triacylglycerol. ${ }^{6,9,10}$

Additionally, SE increases muscle tissue sensitivity to insulin, ${ }^{11,12}$ reduces plasma triglyceride (TAG) concentrations between meals ${ }^{13}$ and has an accentuated effect increasing oxidation of lipids at rest for up to 24 hours after the end of the SE session. ${ }^{14}$ This increase in mobilization and utilization of lipids can be particularly useful for reducing resting PPL. However, very little is known about the true effects of SE on PPL in postmenopausal women.

In view of the above, the objective of this study was to investigate and evaluate the effects of SE on plasma lipoprotein concentrations in postmenopausal women by conducting a review of Brazilian and international literature.

\section{METHODS}

This article is based on a review of current references on the subject identified in Pubmed, EBSCO, Europubmed, Cochrane and Sportdiscus databases. Current articles with publication dates from 1979 to 2012 and with large numbers of citations by well-known researchers into the subject were selected from both Brazilian and international journals. Database searches employed the following keywords: [strength training], [lipoprotein], [exercise], [resistance training], [cardiovascular diseases], [postmenopausal] and [women], plus equivalent expressions in Portuguese. The criterion for inclusion of articles in the study was that they covered a combination of at least two of the keywords above with [strength training].

\section{Utilization of fatty acids during strength training}

The function of lipoproteins is to dissolve and transport lipids, which are generally hydrophobic substances, in an aqueous plasma medium. The most important lipids are free fatty acids, cholesterol and TAG. Triglycerides are the body's most important form of energy storage, deposited in adipose and muscle tissues and consisting of three fatty acids and a glycerol molecule. ${ }^{15}$ Cholesterol is one element in the group of lipids found in the body and is essential for life, since it is used in production of hormones, bile acids and cell membranes. Just $30 \%$ of the cholesterol in the body comes from the diet, the rest is synthesized endogenously. However, excess low density lipoproteins (LDL), very low density lipoproteins (VLDL) and intermediate density lipoproteins (IDL) can build up on the artery walls and provoke CVD. Hypercholesterolemia may be the result of genetic and/or dietary cause; in the majority of cases it is the result of an unbalanced diet that is rich in saturated fats and of a lack of regular physical activity. Cholesterol in circulation 
in the blood is transported by lipoproteins. ${ }^{16}$ The lipoproteins are termed apolipoproteins (apos) and can be classified into four major classes, that can be separated into two groups: (1) TAG-rich, larger and less dense lipoproteins, represented by chylomicrons of intestinal origin (responsible for transporting lipids absorbed by the intestine, originating from the diet and hepatic circulation) and by the very low density lipoproteins (VLDL) of hepatic origin; and (2) cholesterol- rich LDL and high density lipoproteins (HDL). There are also intermediate density lipoproteins, or IDL, and lipoprotein (a) [Lp (a)], which is the result of covalent bonding of an LDL particle to apo (a). ${ }^{17,18}$ From the four classes of lipoproteins listed, total cholesterol (TC), TAG, HDL cholesterol (HDL-c) and LDL cholesterol (LDL-c) are most often assayed in order to test for dyslipidemias and propensity to CVD. ${ }^{16}$ Reference values for diagnosis of dyslipidemias in adults over the age of 20 are shown in Table $1 .{ }^{19}$

In the scientific literature, it is extremely important to understand how the term 'release of TAG' is being applied, in order to determine which of the two mechanisms for release of TAG is under discussion. The first is mediated by breakdown and removal of FA from TAG and the lipoprotein-rich particles that circulate in the blood. Reductions in TAG release may occur due to regulation and increase in the quantity or activity of the LPL enzyme. The second method of clearance of TAG in plasma takes place when a triacylglycerol particle is absorbed in the liver by its receptor. When TAG are ingested in excess, they can deposit on artery walls and form plaques of fat (atheromas) capable of obstructing the passage of blood, stimulating clot formation and contributing to

Table 1. Reference values for diagnosis of dyslipidemia in adults over the age of 20 (adapted from Pearson et al. ${ }^{19}$ ).

\begin{tabular}{ccc}
\hline Lipids & Values & Level \\
\hline Total Cholesterol (TC) & $<200$ & Ideal \\
& $200-239$ & Borderline \\
& $\geq 240$ & High \\
LDL-cholesterol (LDL-c) & $<100$ & Ideal \\
& $100-129$ & Desirable \\
& $130-159$ & Borderline \\
& $\geq 190$ & Very High \\
HDL-cholesterol (HDL-c) & $<40$ & Low \\
& $>60$ & High \\
Triglycerides (TAG) & $<150$ & Ideal \\
& $150-200$ & Borderline \\
& $201-499$ & High \\
& $\geq 500$ & Very High \\
\hline
\end{tabular}

narrowing of blood vessels, particularly if plasma HDL-c concentrations are low ${ }^{20}$. The mechanism of TAG formation and utilization and the FA delivery process stimulated by strength training have been described in detail in a previous study by the same authors ${ }^{21}$.

\section{Menopause}

Menopause is characterized by the end of menstrual and ovulation cycles in woman, which occurs at a mean age of 47 to 54 years. ${ }^{22}$ As the perimenopausal period progresses, the ovaries become resistant to the effect of follicle-stimulating hormone (FSH), which leads to increases in the levels of this hormone. ${ }^{4}$ Additionally, perimenopause is characterized by increase in body mass index (BMI); reduction in physical activity, bone mineral density $^{8}$ and basal metabolism; ${ }^{11}$ increase in ghrelin, irrespective of BMI, and of leptin in non-obese women and by increased oxidative stress and inflammatory markers $;{ }^{23}$ and higher concentrations of TAG and LDL. There is also increased density of LDL particles and lower HDL concentration, which also increases risk of CVD. Furthermore, there is a loss of muscle mass (sarcopenia). Menopause is the depletion of ovarian follicles, leading to an incapacity of production of hormones such as estrogen, which compounds the physiological changes that take place during the perimenopause. ${ }^{24}$

\section{The effects of strength training on lipoproteins in postmenopausal women}

Women share many of the same risk factors for CVD that men are prone to, including family history, poor dietary habits, obesity, smoking, dyslipidemia, hyperhomocysteinemia, dysfibrinogenemia, inactivity, diabetes mellitus and systemic arterial hypertension (HAS). Young women are at a significantly lower risk of CVD when compared to men in the same age group. ${ }^{25}$ However, as age advances, and especially after menopause, their risk approaches that of men. The increased vulnerability is related to reduced serum estrogen levels. These hormones appear to protect women by promoting an antiatherogenic lipid profile and by direct action on the endothelium. ${ }^{5}$ Menopause causes women to lose the cardioprotective effect of endogenous estradiol. ${ }^{25}$ Therefore, any intervention that reduces the risk of development of CVD is particularly relevant to this group. Additionally, the possible effects of cyclic hormone concentrations on metabolism of lipids and 
carbohydrates may confound studies undertaken with premenopausal women. ${ }^{11}$

The metabolic or plurimetabolic syndrome, formerly known as syndrome $\mathrm{X}$, is characterized by a cluster of risk factors for CVD - coronary and cerebral ischemia - peripheral vascular diseases and diabetes mellitus. ${ }^{3,25}$ Its pathophysiology has its origins in resistance to the action of insulin in muscle tissues, which forces the pancreas to produce the hormone in greater quantities. Metabolic syndrome is a disease of modern civilization, linked to obesity resulting from unhealthy nutrition and inactivity. ${ }^{25}$

Aerobic exercise is commonly prescribed as a non-pharmacological strategy for prevention and treatment of obesity and dyslipidemia; whereas strength training, as a possible preventative intervention and for treatment of obesity and dyslipidemia, is still uncertain. ${ }^{5}$ Strength training has inconsistent effects on BMI, body mass and body fat percentage in adults with obesity and with diabetes mellitus type II. ${ }^{26}$ Strength training has proved effective for reducing serum concentrations of TC, TAG and LDL-c and for increasing concentrations of HDL-cholesterol, ;,69-11 however, several authors report that after different periods of strength training (e.g. 8 and 20 weeks), there is no effect on plasma concentrations of lipids or lipoproteins. ${ }^{17,22}$

The inconsistencies and conflicting conclusions in the literature may be the result of differences in the length of training period, the types of strength training, the total volume of training and the intensity of the work performed, and also the characteristics of the participants.

Few studies have investigated the responses of concentrations of lipids and lipoproteins to strength training in postmenopausal women. A study by Fahlman et al. ${ }^{27}$ analyzed the responses of TAG and excess weight in elderly postmenopausal women aged 70 to 87; participants were designated at random to one of two groups, an aerobic training group (3 days/week, 20 to 50 minutes, at $70 \%$ of reserve heart rate) or a strength training group (3 days/week, one and three series, eight exercises, eight repetitions maximum) for ten weeks. The repetitions maximum (RM) were the total number of joint movements that the subjects were able to perform on a given exercise. In this study, the aerobic training group exhibited a significant increase in serum concentrations of TC and HDL-cholesterol, with a concomitant reduction in LDL-cholesterol and TAG. The strength training group also exhibited increased concentrations of HDL-cholesterol and favorable reductions in TC,
LDL-cholesterol and TAG, although these increases and reductions were more significant in percentage terms in the aerobic group. In contrast, Elliott et al. ${ }^{22}$ examined the effects of strength training (3 days/ week, three series of six exercise at $80 \%$ of ten $\mathrm{RM}$ ), for 8 weeks, on concentrations of lipids and lipoproteins in circulation, and also assessed muscle strength in postmenopausal women aged 49 to 62 . The previous study used a sample of women who were on hormone replacement, which could have affected the results.

In one recent study, Wooten et $a .^{5}$ observed a significant reduction in the blood concentrations of TC and LDL-cholesterol in postmenopausal women not on hormone replacement treatment after 12 weeks of strength training, although they did not observe any differences in BMI, body fat percentage or body muscle mass in these women, when compared with a control group. In common with the findings of studies that used strength training, studies of the effects of a single session of SE on lipids and lipoproteins have also reported inconsistent results. In healthy men, Wallace et al. ${ }^{28}$ observed a significant reduction in TAG concentration (20\%) and an increase in HDLcholesterol (11\%) and HDL3-cholesterol (12\%), during the 24 hours following an SE session with a high volume of training at moderate intensity (seven exercises with intensity between eight and $12 \mathrm{RM}$ ). However, when the participants performed a single series with low volume and high intensity (seven exercises at intensities from one to five RM), no significant changes in serum concentrations of lipids or lipoproteins were observed. In contrast, Hill et al. ${ }^{29}$ observed an increase in HDL-c immediately after a single SE session with high intensity (three series, eight exercises and ten RM) in healthy men; however, the change in HDL-c concentration may have been caused by exercise-induced changes to plasmatic volume after the end of the session, since the study did not control for plasma volume.

\section{CONCLUSIONS}

The results in the literature relating to the acute and chronic effects of strength training on metabolism and concentrations of lipoproteins in postmenopausal women are still weak and inconsistent. Irrespective of this, there is consensus among the majority of the authors of the studies reviewed with relation to the suggestion that strength training increases oxidation of fats at rest and that it is a non-pharmacological intervention for management of body weight in postmenopausal women. 


\section{REFERENCES}

1. Van Heek M, Zilversmit DB. Postprandial lipemia and lipoprotein lipase in the rabbit are modified by olive and coconut oil. Arteriosclerosis. 1990;10(3):421-9. http://dx.doi.org/10.1161/01. ATV.10.3.421

2. Gill JM, Hardman AE. Postprandial lipemia: effects of exercise and restriction of energy intake compared. Am J Clin Nutr. 2000;71(2):465-71. PMid:10648259

3. Ballor DL, Poehlman ET. Resting metabolic rate and coronaryheart-disease risk factors in aerobically and resistance-trained women. Am J Clin Nutr. 1992;56(6):968-74. PMid:1442664

4. Prabhakaran B, Dowling EA, Branch JD, Swain DP, Leutholtz $B C$. Effect of 14 weeks of resistance training on lipid profile and body fat percentage in premenopausal women. Bri J Sports Med. 1999;33(3):190-5. http://dx.doi.org/10.1136/bjsm.33.3.190

5. Wooten JS, Phillips MD, Mitchell JB, et al. Resistance exercise and lipoproteins in postmenopausal women. Int J Sports Med. 2011;32(1):7-13. PMid:21086242 PMCid:PMC3354704 http://dx.doi.org/10.1055/s-0030-1268008

6. Costa RR, Lima AC, Tagliari M, Martins Kruel LF. Effects of resistance training on the lipid profile in obese women. J Sports Med Phys Fitness. 2011;51(1):169-77. PMid:21297577

7. Witard OC, Tieland M, Beelen M, Tipton KD, Van Loon LJ, Koopman R. Resistance exercise increases postprandial muscle protein synthesis in humans. Med Sci Sports Exerc. 2009;41(1):144-54. PMid:19092695 http://dx.doi. org/10.1249/MSS.0b013e3181844e79

8. Kemmler W, Lauber D, Weineck J, Hensen J, Kalender W, Engelke $K$. Benefits of 2 years of intense exercise on bone density, physical fitness, and blood lipids in early postmenopausal osteopenic women: results of the Erlangen Fitness Osteoporosis Prevention Study (EFOPS). Arch Intern Med. 2004;164(10):1084-91. PMid:15159265 http://dx.doi.org/10.1001/archinte.164.10.1084

9. Moore DR, Del Bel NC, Nizi KI, et al. Resistance training reduces fasted-and fed-state leucine turnover and increases dietary nitrogen retention in previously untrained young men. J Nutr. 2007;137(4):985-91. PMid:17374665

10. Campbell WW, Haub MD, Wolfe RR, et al. Resistance training preserves fat-free mass without impacting changes in protein metabolism after weight loss in older women. Obesity (Silver Spring). 2009;17(7):1332-9.

11. Poehlman ET, Dvorak RV, DeNino WF, Brochu M, Ades PA. Effects of resistance training and endurance training on insulin sensitivity in nonobese, young women: a controlled randomized trial. J Clin Endocrinol Metab. 2000;85(7):2463-8. PMid:10902794

12. Smutok MA, Reece C, Kokkinos PF, et al. Aerobic versus strength training for risk factor intervention in middle-aged men at high risk for coronary heart disease. Metab Clin Exp. 1993; 42(2):17784. http://dx.doi.org/10.1016/0026-0495(93)90032-J

13. Yarasheski KE, Tebas P, Stanerson B, et al. Resistance exercise training reduces hypertriglyceridemia in HIV-infected men treated with antiviral therapy. J Appl Physiol. 2001; 90(1):133-8. PMid:11133903

14. Treuth MS, Hunter GR, Weinsier RL, Kell SH. Energy expenditure and substrate utilization in older women after strength training: 24-h calorimeter results. J Appl Physiol. 1995;78(6):21406. PMid:7665410
15. DurstineJL,Grandjean PW,CoxCA, Thompson PD.Lipids, lipoproteins, and exercise. J Cardiopulm Rehabil Prevent. 2002;22(6):385-98. http://dx.doi.org/10.1097/00008483-200211000-00002

16. Henry NG. Nonpharmacologic management of low levels of highdensity lipoprotein cholesterol. Am J Cardiol. 2000;86(12):41-5. http://dx.doi.org/10.1016/S0002-9149(00)01469-7

17. Kelley GA, Kelley KS. Impact of progressive resistance training on lipids and lipoproteins in adults: a meta-analysis of randomized controlled trials. Prevent Med. 2009;48(1):9-19. PMid:19013187 http://dx.doi.org/10.1016/j.ypmed.2008.10.010

18. Parks EJ. Recent findings in the study of postprandial lipemia. Cur Atheroscl Reports. 2001; 3(6):462-70. http://dx.doi.org/10.1007/ s11883-001-0036-5

19. Pearson TA, Blair SN, Daniels SR, et al. AHA Guidelines for primary prevention of cardiovascular disease and stroke: 2002 update. Circulation. 2002;106(3):388-91. PMid:12119259 http://dx.doi. org/10.1161/01.CIR.0000020190.45892.75

20. Graham TE. Exercise, postprandial triacylglyceridemia, and cardiovascular disease risk. Can J Appl Physiol. 2004;29(6):781-99. PMid:15630150 http://dx.doi.org/10.1139/h04-051

21. Correa CS, Teixeira BC, Bittencourt A, Macedo RCO, ReisschakOliveira A. Postprandial lipemia and cardiovascular diseases: the beneficial role of strength exercise. J Vasc Bras. 2014; 13:123-30.

22. Elliott KJ, Sale C, Cable NT. Effects of resistance training and detraining on muscle strength and blood lipid profiles in postmenopausal women. Bri J Sports Med. 2002;36(5):340-4. PMCid:PMC1724556 http://dx.doi.org/10.1136/bjsm.36.5.340

23. Zotou E, Magkos F, Koutsari C, et al. Acute resistance exercise attenuates fasting and postprandial triglyceridemia in women by reducing triglyceride concentrations in triglyceriderich lipoproteins. Eur J Appl Physiol. 2010;110(4):869-74. PMid:20607278 http://dx.doi.org/10.1007/s00421-010-1561-0

24. Asikainen TM, Kukkonen-Harjula K, Miilunpalo S. Exercise for health for early postmenopausal women: a systematic review of randomised controlled trials. Sports Med. 2004; 34(11):753-78. PMid:15456348 http://dx.doi. org/10.2165/00007256-200434110-00004

25. Fenkci S, Sarsan A, Rota S, Ardic F. Effects of resistance or aerobic exercises on metabolic parameters in obese women who are not on a diet. Advances in Ther. 2006;23(3):404-13. http://dx.doi. org/10.1007/BF02850161

26. Hills AP, Shultz SP, Soares MJ, et al. Resistance training for obese, type 2 diabetic adults: a review of the evidence. Obes Rev. 2010;11(10):740-9. PMid:20003071 http://dx.doi. org/10.1111/j.1467-789X.2009.00692.x

27. Fahlman MM, Boardley D, Lambert CP, Flynn MG. Effects of endurance training and resistance training on plasma lipoprotein profiles in elderly women. J Gerontol Biol Sci Med Sci. 2002;57(2):B54-60. http://dx.doi.org/10.1093/gerona/57.2.B54

28. Wallace MB, Moffatt RJ, Haymes EM, Green NR. Acute effects of resistance exercise on parameters of lipoprotein metabolism. Med Sci Sports Exerc. 1991;23(2):199-204. PMid:2017015 http:// dx.doi.org/10.1249/00005768-199102000-00009

29. Hill S, Bermingham MA, Knight PK. Lipid metabolism in young men after acute resistance exercise at two different intensities. J Sci Med Sport. 2005;8(4):441-5. http://dx.doi.org/10.1016/ S1440-2440(05)80059-3 
Correspondence Cleiton Silva Correa

Universidade Regional Integrada do Alto Uruguai e das Missões (URI)

Rua José Bonifácio, 3149

CEP 97800-000 - São Luiz Gonzaga (RS), Brazil Tel.: (55) 3352-4220

E-mail: cleitonesef@yahoo.com.br

Author information

CSC é Doutor em Ciências do Movimento Humano pela Universidade Federal do Rio Grande do Sul (UFRGS) e Coordenador do Curso de Educação Física da URI-SLG.

BCT é Mestre em Ciências do Movimento Humano pela Universidade Federal do Rio Grande do Sul (UFRGS).

$A B$ é Bacharel em Educação Física pela Universidade Federal do Rio Grande do Sul (UFRGS).

ARO é Doutor em Fisiologia e Professor Titular do Curso de Educação Física da Universidade Federal do Rio Grande do Sul

(UFRGS).

Author contributions Conception and design: CSC, BCT, AB, ARO Analysis and interpretation: $C S C, B C T, A B, A R O$

Data collection: CSC

Writing the article: $C S C, B C T, A B, A R O$ Critical revision of the article: $C S C, B C T, A B, A R O$ Final approval of the article*: CSC, BCT, AB, ARO Overall responsibility: $C S C, B C T, A B, A R O$

Obtained funding: None.

*All authors have read and approved of the final version of the article submitted to J Vasc Bras. 